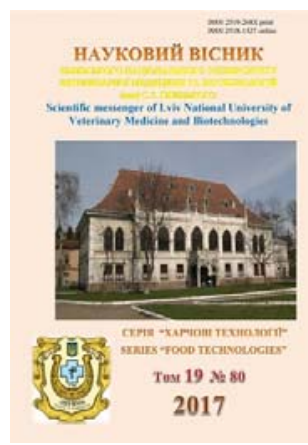

Науковий вісник Львівського національного університету ветеринарної медицини та біотехнологій імені С.3. Гжицького

Scientific Messenger of Lviv National University of Veterinary Medicine and Biotechnologies

doi:10.15421/nvlvet8024

ISSN 2519-268X print

ISSN 2518-1327 online

$\underline{\text { http://nvlvet.com.ua/ }}$

\title{
Продовження термінів зберігання м'яса шляхом підвищення стресостійкості свиней
}

\author{
В.В. Цигура, Л.Г. Віннікова \\ viktoriya.tsygura@ukr.net, vinnikova.luda@mail.ru \\ Одеська національна академія харчових технологій, \\ вул. Канатна, 112, Одеса, 65000, Україна
}

\begin{abstract}
Стаття присвячена вивченню можливості продовження термінів зберігання свинини за допомогою використання у відгодівлі свиней речовин, що підвищують стеростійкість свиней. М'ясо забійних тварин є сприятливим пожсивним середовищем для розвитку багатьох мікроорганізмів. На безпечність $і$ якість м'яса має значний вплив бактеріальне обсіменіння під час первинної переробки туш, зумовлене внутрішніми та зовнішніми чинниками. На якість та технологічну придатність і безпечність свинини впливає ряд факторів, серед яких не останнє місие займає стійкість свиней до дії зовнішніх факторів. У здорових тварин прижиттєве забруднення окремих органів відбувається за умов ослаблення природного імунітету під впливом різних несприятливих факторів з кишечнику через лімфатичні і кровоносні судини. Вживання такого м'яса може бути небезпечним для споживача. На якість і безпечність м'яса та м'ясних продуктів впливає мікробіологічний стан м'яса. Важливу роль у зменшенні бактеріального обсіменіння відіграє якісне виконання технологічних етапів, починаючи з відгодівлі тварин, транспортування, передзабійної витримки, забою та первинної переробки. Важливим фактором, який впливає на терміни зберігання м'яса, є активність води. У технології м'яса і м'ясопродуктів має значення досить вузький діапазон зміни активності води - від 0,80 до 1,00. Значення активності води відіграє вирішальну роль у забезпеченні безпеки $i$ збереженні їх якості, тому шо значення $a_{w}$ нижчі ніж 0,95 виключають можливість активного зростання більшості патогенних мікроорганізмів, а також мікроорганізмів, шчо викликають псування продуктів і харчові отруєння (Cl. botulinum, Cl. perfringens, Bacillu, Citrobacter, Enterobacter, Escherichia, Proteus, SalmonelIa, Pseudomonas, Corynobacterium та ін.). При дослідженні виявлено, шо після забою кількість МАФАнМ, КУО/г, відповідають нормативним показникам, на 5 та 10 добу загальна кількість мікроорганізмів зростає, але не перевищує встановлених вимог. На 15 добу після забою в контрольній групі показник перевищив допустиму норму на $3 \cdot 10^{5} \mathrm{KУO,} \mathrm{а} \mathrm{в} \mathrm{дослідних} \mathrm{групах} \mathrm{відповідає} \mathrm{нормі.}$ Патогенних організмів роду Salmonella не виявлено. В процесі зберігання на 5 добу кількість бактерій Enterobacteriaceae зростає, а на 10 добу різко зменшується в зв'язку з пригніченням активності бактерій під дією холоду та зміною рН середовища. Доведено можливість продовження термінів зберігання свинини за рахунок використання в раціонах природних речовин, які впливають на стресочутливість свиней.
\end{abstract}

Ключові слова: свинина, мікроорганізми, активність води, терміни зберігання, мікробіологічний стан м'яса, рН, Патогенні організми роду Salmonella, бактерій Enterobacteriaceae

\section{Продления срока хранения мяса путем повышения стрессоустойчивости свиней}

\author{
В.В. Цигура, Л.Г. Винникова \\ viktoriya.tsygura@ukr.net, vinnikova.luda@mail.ru \\ Одесская национальная академия пищевых технологий, \\ ул. Канатная, 112, Одесса, 65000, Украина
}

\begin{abstract}
Статья посвящена изучению возможности продления сроков хранения свинины с помощью использования в откорме свиней веществ, повышающих стрессоустойчивость животных. Мясо убойных животных является благоприятной питательной средой для развития многих микроорганизмов. На безопасность и качество мяса может влиять бактериальное обсеменение при первичной переработки туш, обусловленное внутренними и внешними факторами. На качество и техно-
\end{abstract}

Citation:

Tsyhura, V.V., Vinnikova, L.G. (2017). Extension of preservation terms for meat by increasing the stress resistance of pork. Scientific Messenger LNUVMB, 19(80), 115-118. 
логическую пригодность, безопасность свинины влияет ряд факторов, среди которых не последнее место занимает устойчивость свиней к воздействию внешних факторов. У здоровых жсвотных прижизненное загрязнение отдельньх органов происходит в условиях ослабления естественного иммунитета под влиянием различных неблагоприятных факторов из кишечника через лимфатические и кровеносные сосуды. Употребление такого мяса может быть опасным для потребителя. На качество и безопасность мяса и мясных продуктов влияет микробиологическое состояние мяса. Важную роль в уменьшении бактериального обсеменения играет качественное выполнение технологических этапов, начиная с откорма животных, транспортировки, предубойной выдержки, убоя и первичной переработки. Важным фактором, который влияет на сроки хранения мяса, является активность воды. В технологии мяса и мясопродуктов имеет значение достаточно узкий диапазон изменения активности воды - от 0,80 до 1,00. Значение активности воды играет решаюшую роль в обеспечении безопасности и сохранении их качества, так как значения аж ниже 0,95 исключают возможность активного роста больиинства патогенных микроорганизмов, а также микроорганизмов, которие вызывают порчу продуктов и пищевые отравления (Cl. Botulinum, Cl. Perfringens, Bacillu, Citrobacter, Enterobacter, Escherichia, Proteus, SalmonelIa, Pseudomonas, Corynobacterium и др.). При исследовании обнаружено, что после забоя количество МАФАнМ, КОЕ/г, соответствуют требованиям нормативным показателям, на 5 и 10 сутки общее количество микроорганизмов растет, но не превышает установленных требований. На 15 сутки после убоя в контрольной группе показатель превысил допустимую норму

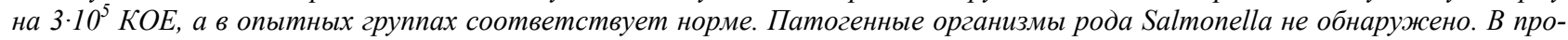
иессе хранения на 5 сутки хранения количество бактерий Enterobacteriaceae растет, а на 10 сутки резко уменьиается в связи с угнетением активности бактерий под действием холода и изменением рН среды. Доказана возможность продления сроков хранения свинины за счет использования в рационах природных веществ, которые влияют на стрессочувствительность свиней.

Ключевые слова: свинина, микроорганизмы, активность воды, сроки хранения, микробиологическое состояние мяса, pH, патогенные организмы рода Salmonella, бактерий Enterobacteriaceae

\title{
Extension of preservation terms for meat by increasing the stress resistance of pork
}

\author{
V.V. Tsyhura, L.G. Vinnikova \\ viktoriya.tsygura@ukr.net, vinnikova.luda@mail.ru \\ Odessa academy of food technologies, \\ Kanatna str., 112, Odessa, 65000, Ukraine
}

The article is devoted to the opportunity of extension of preservation terms for meat by increasing the stress resistance of pork, using the feeding elements improving the stress resistance of pigs. Animal meat is a good breeding ground for a great number of bacteria. Bacterial contamination, during the primary procession of carcasses, determined by inner and outer factors, greatly influences the safety of meat. Quality, safety and productability of pork is influenced by several factors, among them stress resistance of pigs has a great role. In healthy animals, pollution of some organs happens under the conditions of natural immunity lowering, under the influence of different unfavorable factors from the bowel through lymph and blood vessels. Consumption of such meat may be dangerous. Quality and safety of meat and meat products are influenced by bacterial contamination of meat. A great role is played here by appropriate technology, such as animal feeding, transportation, before slaughtering activities and primary procession. An important point, influencing the preservation terms of meat, is water activity. The technology of meat and meat products, has relatively small level of changes of water activity from 0.80 to 1.00. The level of water activity has a great role in preservation and quality of meat, because levels of water activity lower then 0.95, eliminate the possibility of active development for the most types of pathogenic microorganisms and microorganisms causing spoiling of meat products and foodborn diseases (Cl. botulinum, Cl. perfringens, Bacillu, Citrobacter, Enterobacter, Escherichia, Proteus, SalmonelIa, Pseudomonas, Corynobacterium etc.). The research has determined that after slaughtering, mesophilic and optionally anaerobic microorganisms are in measures of norm, on the 5 and 10 day the average quantity of microorganism increases but still is in measures of norm. On the 15 day after slaughtering, the level of microorganism, in test sample exceeded the norm for $3 \cdot 10^{5}$ and in researched group is in measures of norm. Salmonella is not found. While preservation, on the 5 day quantity of bacteria Enterobacteriaceae increases and decreases on the 10 day due to decaying activity of bacteria in frost and changes in pH environment. The possibility to extend the preservation terms for pork, using natural matters influencing the stress resistance.

Key words: pork, microorganism, water activity, microbiological contamination, pH, Salmonella, Enterobacteriaceae.

\section{Вступ}

М'ясо забійних тварин є сприятливим поживним середовищем для розвитку багатьох мікроорганізмів. На безпечність і якість м’яса має значний вплив бактеріальне обсіменіння під час первинної переробки туш, зумовлене внутрішніми та зовнішніми чинниками (Vinnikova, 2006).

На якість та технологічну придатність та безпечність свинини впливає ряд факторів, серед яких не останнє місце займає стійкість свиней до дії зовнішніх факторів.
У здорових тварин прижиттєве забруднення окремих органів відбувається за умов ослаблення природного імунітету під впливом різних несприятливих факторів 3 кишечнику через лімфатичні та кровоносні судини. До внутрішніх факторів слід віднести: відсутність відпочинку тварин перед забоєм та передзабійної голодної витримки, хвороби, отруєння тощо. Зокрема, таким шляхом у м'ясо можуть потрапляти бактерії роду Salmonella, які, перебуваючи в травному каналі тварини, при ослабленні захисних властивостей стінки кишечнику під час захворювання, виснаження, втоми тощо поширюються в усьому тілі, а 
після забою виявляються в м'ясі. Вживання такого м'яса може бути небезпечним для споживача. Зовнішніми джерелами обсіменіння м'яса бактеріями можуть бути: вода, що використовується під час первинної переробки туш, руки працівників, технологічне обладнання тощо (Yancheva et al., 2009; Fatyanov et al., 2013). Важливу роль у зменшенні бактеріального обсіменіння відіграє якісне виконання технологічних етапів, починаючи 3 відгодівлі тварин, транспортування, передзабійної витримки, забою та первинної переробки.

Постановка проблеми. 3 точки зору фізіології, стрес - це природна реакція організму на подразник, мобілізуюча його захисно-пристосувальні механізми. У нормі здорова тварина успішно долає стрес і адаптується до нових умов існування. Але 3 середини минулого століття науковці стали помічати, що все більше і більше свиней неадекватно реагують на стреси. Вплив навіть незначного подразника негайно відбивався на продуктивності свиней та якості м'яса.

Вегето-судинні розлади, викликані стресом, своєю чергою впливають на порушення теплообміну, через що стресочутливі свині постійно страждають від перегріву, що призводить до злоякісної гіпертермії, або MHS - синдрому (від англ. Malignant Hypertermia Syndrome - синдром злоякісної гіпертермії). При цьому температура тіла тварини може підвищитися до $41{ }^{\circ} \mathrm{C}$. При MHS-синдромі ще за життя свині починається розпад білків м'язової тканини, що призводить до низької поживної цінності та поганої збереженості м'яса.

Але головне, що повинно турбувати технолога це підвищена швидкість розпаду глікогену в м'язовій тканині у свиней, уражених PSS (синдром викликано підвищеною витратою кортикостероїдів (адреналіну, деоксікортікостерона і АКТГ) при хронічному стресі) або MHS-синдромом, оскільки інтенсивність обмінних процесів в м'язах визначає якість свинини. М'ясо, отримане від тварин, що піддавалися стресу, має вади PSE. Така свинина вимагає додаткових витрат праці, часу і матеріальних засобів. Тому є важливим боротися не $з$ наслідками, а з причиною даного явища.

Нерідко використовують транквілізатори і адаптогени. Транквілізатори пригнічують реактивність організму і згладжують наслідки стресу, затримуючи проведення нервового імпульсу.

Адаптогени на реактивність організму не впливають. Їхня дія заснована на підвищенні стійкості організму до дії несприятливих чинників. Велике значення в профілактиці стресів має додавання $\alpha$ токоферолацетату в корм. А також використання кормів, які в своєму складі містять поліненсичені жирні кислоти та вітаміни групи В.

Важливим фактором, що впливає на терміни зберігання м'яса, є активність води. Активність води (aw)це кількість незв'язаної води у будь-якому продукті, яка $є$ доступною для мікроорганізмів i може бути використана для їхньої життєдіяльності. Взаємозв'язок між станом води та розвитком мікроорганізмів у продуктах харчування довів у 1952 р. W.J. Scott, який і запропонував для визначення якості продуктів використовувати показник «активність води» (англ. «water activity» - aw). При цьому не слід плутати це 3 достатньо широко розповсюдженим поняттям «активність води», відомим як придбання природною водою певної якості під впливом деяких фізичних методів іiі обробки - електродіаліз, магнетизація тощо.

За допомогою активності проводять оцінку ступеня участі води в різних хімічних, біохімічних реакціях і т. д. (Fatyanov and Aleynikov, 2005).

Мета роботи - довести можливість продовження термінів зберігання м'яса шляхом покращення мікробіологічного стану свинини.

\section{Матеріал і методи досліджень}

Матеріалом для дослідження слугували зразки, відібрані від туш контрольної та дослідних груп (контрольна група - раціон господарства, I дослідна група - 20\% раціону люпин жовтий безалкалоїдний, II дослідна група - 20\% люпин жовтий безалкалоїдний та 200 мг/кг корму $\alpha$-токоферол ).

Мікробіологічні дослідження проводили за загальноприйнятими методиками згідно з чинними в Україні нормативно-правовими актами.

\section{Результати та їх обговорення}

Мікробіологічні показники є важливою характеристикою безпечності харчових продуктів. Як можемо бачити 3 таблиці 1 , після забою кількість МАФАнМ, КУО/г відповідають нормативним показникам, на 5 та 10 добу загальна кількість мікроорганізмів зростає, але не перевищує встановлених вимог. При дослідженні м'яса на 15 добу після забою в контрольній групі показник перевищив допустиму норму на $3 \cdot 10^{5}$ КУО, а в дослідних групах відповідає нормі. Патогенних організмів роду Salmonella не виявлено.

В процесі зберігання на 5 добу зберігання кількість бактерій Enterobacteriaceae зростає, а на 10 добу різко зменшується в зв'язку з пригніченням активності бактерій під дією холоду та зміною $\mathrm{pH}$ середовища.

Вода в м'ясі, як і в будь-якому біологічному матеріалі, утримується всіма формами зв'язку. Однак характер і міцність зв'язків неоднакова. Найбільш міцно зв'язана абсорбційна волога.

Із загальної кількості води, що міститься в харчових продуктах, мікроорганізми, наприклад, можуть використовуватися для своєї життєдіяльності лише певну «активну» їі частину.

Як відомо, при розчиненні речовин у воді між водою і молекулами цих речовин відбувається реакція взаємодії, яка характеризується тим, що певна кількість молекул води зв'язується з молекулами розчиненої речовини, зменшуючи кількість незв'язаних (вільних) молекул води. Для кожного виду мікроорганізмів існує максимальне, мінімальне і оптимальне значення активності води. Відхилення значення $\mathrm{A} w$ від оптимального приводить до сповільнення процесів життєдіяльності мікроорганізмів, а інколи й до їньої загибелі.

Аналогічний процес спостерігається в м'ясі: чим більше молекул води зв'язано з розчиненими в ній 
інгредієнтами (сіллю, полісахаридами, функціональними добавками тощо), тим менше води залишається для розмноження і росту мікроорганізмів, тим тривалішим може бути строк його зберігання.

Активність води $\mathrm{a}_{\mathrm{w}}$ виражається значеннями від 0,00 до 1,00. Значення $\mathrm{a}_{\mathrm{w}}=1,00$ відповідає дистильованій воді, а значення $\mathrm{a}_{\mathrm{w}}=0,00-$ стану абсолютно зневодненого продукту.

У технології м'яса і м'ясопродуктів має значення досить вузький діапазон зміни активності води - від 0,80 до 1,00. Значення активності води відіграє вирішальну роль у гарантуванні безпеки і збереженні ї якості, тому що значення $\mathrm{a}_{\mathrm{w}}$ нижчі ніж 0,95 виключають можливість активного зростання більшості патогенних мікроорганізмів, а також мікроорганізмів, що викликають псування продуктів і харчові отруєння
(Cl. botulinum, Cl. perfringens, Bacillu, Citrobacter, Enterobacter, Escherichia, Proteus, Salmonella, Pseudomonas, Corynobacterium та ін.) А значення показника $\mathrm{a}_{\mathrm{w}}$ нижчі ніж 0,85 виключають можливість зростання дріжджів і цвілі. До зниження активності води особливо чутливі грамнегативні бактерії, якими в основному представлена гнилісна мікрофлора (Yancheva et al., 2009).

Для охолодженого м'яса NOR значення $\mathrm{a}_{\mathrm{w}}$ становить 0,990, при такому показнику активності води свинина зберігається при $0-2{ }^{\circ} \mathrm{C}$ може протягом 10 діб. При вищій $\mathrm{a}_{\mathrm{w}}$ терміни зберігання свинини скорочуються.

Результати дослідження дослідних груп свиней наведені в таблиці 2.

Мікробіологічні дослідження свинини

\begin{tabular}{|c|l|c|c|c|c|}
\hline \multicolumn{2}{|c|}{ Показник } & Мазки відбитки & $\begin{array}{c}\text { КМАФАнМ, КУО } \\
\text { в 1 г не більше }\end{array}$ & БГКП, КУО в 1 г & $\begin{array}{c}\text { Патогенні, в тому числі } \\
\text { сальмонели в 25 грамах }\end{array}$ \\
\hline \multirow{4}{*}{ Контрольна група } & Після забою & Не виявлено & $3,2 \cdot 10^{6}$ & $9,5 \cdot 10^{2}$ & Не виявлено \\
\cline { 2 - 6 } & 5 доба & - & $3,5 \cdot 10^{6}$ & $9,8 \cdot 10^{2}$ & Не виявлено \\
\cline { 2 - 6 } & 10 доба & - & $5 \cdot 10^{6}$ & $4,8 \cdot 10^{2}$ & Не виявлено \\
\cline { 2 - 6 } & 15 доба & - & $5,3 \cdot 10^{6}$ & $1,2 \cdot 10^{3}$ & Не виявлено \\
\hline \multirow{5}{*}{ Дослідна группа I } & Піся забою & Не виявлено & $3,0 \cdot 10^{6}$ & $9,4 \cdot 10^{2}$ & Не виявлено \\
\cline { 2 - 6 } & 5 доба & - & $3,2 \cdot 10^{6}$ & $9,7 \cdot 10^{2}$ & Не виявлено \\
\cline { 2 - 6 } & 10 доба & - & $4,5 \cdot 10^{6}$ & $4,55 \cdot 10^{2}$ & Не виявлено \\
\cline { 2 - 6 } & 15 доба & - & $4,9 \cdot 10^{6}$ & $1,0 \cdot 10^{3}$ & Не виявлено \\
\hline \multirow{5}{*}{ Дослідна группа II } & Після забою & Не виявлено & $2,9 \cdot 10^{6}$ & $9,4 \cdot 10^{2}$ & Не виявлено \\
\cline { 2 - 6 } & 5 доба & - & $3,1 \cdot 10^{6}$ & $9,7 \cdot 10^{2}$ & Не виявлено \\
\cline { 2 - 6 } & 10 доба & - & $4,5 \cdot 10^{6}$ & $4,4 \cdot 10^{2}$ & Не виявлено \\
\cline { 2 - 6 } & 15 доба & - & $4,8 \cdot 10^{6}$ & $9,8 \cdot 10^{2}$ & Не виявлено \\
\hline \multicolumn{2}{|l|}{ Нормативний показник } & Не виявлено & $5 \cdot 10^{6}$ & $1 \cdot 10^{3}$ & Не виявлено \\
\hline
\end{tabular}

Табличя 2

Активність води

\begin{tabular}{|l|c|c|c|}
\hline Показник & Контрольна група & Дослідна група I & Дослідна група II \\
\hline $\mathrm{a}_{\mathrm{W}}$ & $0,991 \pm 0,003$ & $0,990 \pm 0,003$ & $0,989 \pm 0,003$ \\
\hline
\end{tabular}

В контрольній групі показник активності води вищий порівняно $з$ дослідними, що й обумовлює коротші терміни зберігання свинини.

\section{Висновки}

1. Доведено можливість продовження термінів зберігання свинини за рахунок використання в раціонах природних речовин, які впливають на стресочутливість свиней.

2. Продовжено терміни зберігання свинини 310 до 15 діб.

3. Показано, що корекція раціонів годівлі з включенням жовтого безалкалоїдного люпину та $\alpha$-токоферолу знижує розвиток небажаної мікрофлори.

Перспективи подальших досліджень. Дослідження будуть спрямовані на можливості підвищення стійкості свинини до окислювальних процесів зберігання.

\section{Бібліографічні посилання}

Natsional'nyy standart Ukrayiny (2011). Myaso. Svynyna $\mathrm{v}$ tushakh i pivtushakh. Tekhnichni umovy: DSTU
7158:2010. Kyyiv: Derzhspozhyvstandart Ukrayiny (in Ukrainian).

Yancheva, M.O., Peshuk, L.V., Dromenko, O.B. (2009). Fizyko-khimichni ta biokhimichni osnovy tekhnolohiyi myasa ta myasoproduktiv. Navchal'nyy posibnyk. K.: Tsentr uchbovoyi literatury (in Ukrainian).

Vinnikova, L.G. (2006). Tehnologiya myasa i myasnih produktov. Uchebnik. Kiev: Firma «INKOS» (in Russian).

Fatyanov, E.V., Sidorov, S.A., Ryipalov, A.V., Evteev, A.V. (2013). Aktivnost vodyi myasnyih farshevyih sistem. Nauchnoe obrazovanie. 3, 91-96 (in Russian).

Fatyanov, E.V., Aleynikov, A.K. (2005). Analiz sovremennogo sostoyaniya sredstv opredeleniya pokazatelya aktivnosti vodyi $\mathrm{v}$ pischevyih produktah. Vavilovskie chteniya - 2005: mater. Vser.NPK. Saratov, 177-180 (in Russian). 